THE TYRANNY OF OPINION 





\section{THE TYRANNY OF OPINION}

Honor in the Construction of the Mexican Public Sphere Pablo Piccato

Duke University Press Durham and London 2010

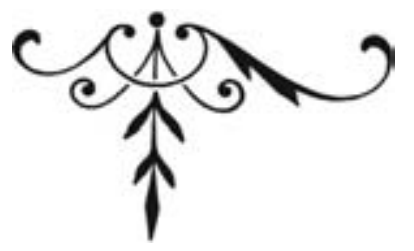


(C) 2010 Duke University Press

All rights reserved

Printed in the United States of America on acid-free paper $\infty$

Designed by C. H. Westmoreland

Typeset in Warnock with Whitman display

by Keystone Typesetting, Inc.

Library of Congress Cataloging-in-Publication Data

Piccato, Pablo.

The tyranny of opinion : honor in the construction of

the Mexican public sphere / Pablo Piccato.

p. cm.

Includes bibliographical references and index.

IS B N 978-o-8223-4653-1 (cloth : alk. paper)

IS B N 978-0-8223-4645-6 (pbk. : alk. paper)

1. Honor-Political aspects-Mexico. 2. Mexico-Politics

and government-1861-1867. 3. Mexico-Politics and

government-1867-1910. 4. Mexico-Politics and

government-1910-1946. I. Title.

F 1233.P 522010

972.08-dc22 2009039110 
para Xóchitl, Catalina,

Aída, Ana y Cecilia 

¡Cómo lucha la conciencia

con la virtud que se abate!

¿Qué gran campo de combate

el campo de la existencia!

(How conscience fights

against declining virtue!

What a great field of combat

is the field of existence)

"VELA," JUAN DE DiOS PEZA

En la estación del metro Balderas, ahí quedó embarrada mi reputación.

(At the Balderas subway station, where my reputation was stained.)

“METRO BALDERAS," EL TRI AND

ROCKDRIGO GONZÁLEZ 
